\title{
QUANTITATION OF HCV RNA IN LIVER OF PATIENTS WITH CHRONIC HEPATITIS C
}

\author{
Ana de Lôrdes Candolo MARTINELLI ${ }^{1,4}$, David BROWN ${ }^{1}$, Allun MORRIS ${ }^{1}$, \\ Amar DHILLON $^{2}$, Peter DAYLEY ${ }^{3}$ and Geoffrey DUSHEIKO ${ }^{1}$
}

\begin{abstract}
Background/Aims - Liver HCV RNA has been quantitated in few studies and the feasibility and the role of this parameter in the evaluation of patients with chronic HCV hepatitis still warrant study. Our aim was to determine the concentrations of HCV RNA in the liver of chronic HCV patients and to correlate the results with serum viral load. We also studied the relation of levels of HCV RNA in the liver with serum aminotransferases levels and with the presence of cirrhosis. Methods - Twenty patients (14 males, aged 28 to 61 years) were studied. Twelve were infected by HCV type 1, six by type 3 and one by type 5. Percutaneous liver biopsy samples were obtained from 14 patients, and the remainder from liver explant in patients undergoing OLT. Twelve had chronic hepatitis and eight cirrhosis. HCV RNA levels were determined by bDNA. Results - HCV RNA levels below the detection limit were found in one liver and in five serum samples. HCV RNA (mean $\pm S D$ ) was $2.1 \times 10^{8} \pm 2.2 \times 10^{8} \mathrm{Eq} / \mathrm{gm}$ in the liver and $94 \times 10^{5} \pm 93 \times 10^{5} \mathrm{Eq} / \mathrm{mL}$ in serum, with a significant correlation between these values $(r=0.89 ; P<0.0001)$. Serum HCV RNA levels were significantly lower $(P=0.001)$ in cirrhotic than in chronic hepatitis patients, while the groups did not differ in liver HCV RNA levels. No correlation was observed between liver or serum HCV RNA and serum ALT or AST. Conclusions - Quantitation of HCV RNA is possible even in small liver samples. Although average levels are more than one log higher than those observed in serum, hepatic concentrations correlate with those observed in serum. The application of this technology to monitoring antiviral therapy and understanding the pathogenesis of the disease remains to be determined.
\end{abstract}

HEADINGS - RNA, viral. Hepatitis C. Hepatitis C-like viruses. Liver. Genotype.

Financial support: Conselho Nacional de Desenvolvimento Científico e Tecnológico (CNPq) and Fundação de Apoio ao Ensino e Pesquisa e Assistência (FAEPA) of The University Hospital of FMRP-USP, Ribeirão Preto, SP, Brasil.

University Department of Medicine. Royal Free Hospital and School of Medicine, London, UK.

Department of Pathology, Royal Free Hospital and School of Medicine.

Chiron Corporation, Emeryville, CA, USA.

Present affiliation: Department of Medicine, School of Medicine of Ribeirão Preto, University of São Paulo, Ribeirão Preto, São Paulo, Brazil. Address for correspondence: Dra. Ana L.C. Martinelli - Department of Medicine - School of Medicine of Ribeirão Preto - University of São Paulo - Av. Bandeirantes, 3900 14049-900 - Ribeirão Preto, SP, Brazil. E-mail: adlcmart@fmrp.usp.br 


\section{INTRODUCTION}

The mechanisms mediating hepatocellular injury in chronic hepatitis $\mathrm{C}$ infection are not completely clear. Evidence suggests that both a direct viral cytopathic injury and immunologically mediated hepatocellular damage occur ${ }^{(12,13,18)}$. The role of the level of HCV RNA in serum in affecting the progression of hepatitis and its prognosis is still unclear ${ }^{(2)}$. However higher levels of HCV RNA are associated with lower rate of response to interferon therapy ${ }^{(4,7,19,20)}$. In addition, some $\mathrm{HCV}$ virus genotypes can be associated with higher viraemia levels $^{(5,8,11)}$. Quantitative evaluation of serum HCV RNA appears to be of importance in the management of the patient ${ }^{(9)}$ and it has been suggested as a parameter to decide what doses of IFN should be employed ${ }^{(3)}$.

It is assumed that liver concentration reflects serum concentration. However, there are few studies in which HCV RNA has been simultaneously quantitated in serum and liver samples ${ }^{(1,6,10,14,17)}$. Moreover, the disease is complex, and both hepatic and extrahepatic sites of replication may contribute to the viral levels observed in serum. In addition, the relation between liver HCV RNA viral load and activity or stage of the liver disease remains unclear.

The objectives of the present work were to assess the feasibility of measuring HCV RNA levels in small tissue samples from percutaneous liver biopsies and to study their correlation with the serum levels of HCV RNA in patients with chronic HCV liver disease. Additionally we evaluated the relation of viral load with the serum levels of aminotransferases and with the presence of hepatic cirrhosis.

\section{PATIENTS AND METHODS}

\section{Patients and study design}

The study population comprised 20 patients (14 men and 6 women aged 28 to 61 years, mean 43.5 years). All patients were antiHCV positive by second generation ELISA (ORTHO diagnostics, Rariran, New Jersey, USA) and by RIBA-2 for at least 6 months. Written consent was obtained from all patients before the study, which was approved by the Ethics Committee of the Royal Free Hospital School of Medicine, London, England. The study was conducted in accordance with the Declaration of Helsinki.

Serum ALT and AST levels were measured in each patient to ascertain the biochemical activity of the disease. Serum and liver samples for quantitation of HCV RNA were obtained on the same day. Serum was stored at $-20^{\circ} \mathrm{C}$. The liver samples were collected under strictly sterile conditions. A portion of the biopsy specimen was immediately frozen in liquid nitrogen and stored frozen at $-70^{\circ} \mathrm{C}$ until processed for quantitative HCV RNA assay, whilst the other fragment of the biopsy was processed for histology by routine methods. Liver samples were obtained from 14 patients submitted to percutaneous liver biopsies for diagnosis or clinical management and the remainder from liver explants in patients undergoing orthotopic liver transplantation (OLT).

\section{Methods}

\section{HCV RNA measurement:}

a) Serum: concentrations of HCV RNA were determined by the quantitative bDNA (version 1) signal amplification assay (Quantiplex HCV RNA assay, Chiron corporation) according to the manufacturer's instructions. This test is based upon specific hybridisation of virus RNA in the sample by synthetic oligonucleotides to the highly conserved 5-untranslated region and core gene of HCV RNA immobilised on the surface of a microwell plate. Synthetic bDNA amplifier molecules and multiple copies of an alkaline phosphataselinked probe are hybridised to the immobilised complex. The complex is incubated with a chemo-luminescent substrate and the light emission is measured, the signal being proportional to the level of target nucleic acid. The quantity of HCV RNA in the sample is determined from a standard curve. The detection limit of the test is $350,000 \mathrm{HCV}$ RNA equivalents per $\mathrm{mL}$. These measurements were corrected for possible differences in efficiency of measurement of HCV RNA of different genotypes $^{(16)}$.

b) Liver: the liver sample was weighed and homogenised and RNA was isolated according to the following procedure. The homogenisation was done using pellet pestle mixers and matched tubes to which guanidine $\mathrm{HCl}(6 \mathrm{M})$ homogenization solution $(0.5 \mathrm{~mL}$ per $25 \mathrm{mg}$ of tissue or a final volume of $0.5 \mathrm{~mL}$ for smaller samples) was added. Sarcosyl (20\%) was added in order to obtain a final concentration of $0.5 \%$. After vortexing and holding at $2-8{ }^{\circ} \mathrm{C}$ for 5 minutes, the specimen was centrifuged $(12,000 \mathrm{G} \times 1$ minute $)$ and the supernatant was collected. Ten microlitres of poly A $(10 \mathrm{mg} / \mathrm{mL})$ was added to each tube and the content was gently vortexed. A $0.25 \mathrm{~mL}$ amount of $100 \%$ ethanol was added to each tube and mixed very thoroughly. The preparation was left to stand at $-20^{\circ} \mathrm{C}$ overnight, centrifuged at 12,000 G for 20 minutes and the supernatant carefully aspirated. An additional amount of $0.5 \mathrm{~mL} \mathrm{70 \%} \mathrm{ethanol} \mathrm{was} \mathrm{added} \mathrm{to}$ each tube. The tubes were then vortexed and centrifuged again for 20 minutes. The supernatant was aspirated and the pellet dried down with a rotary vacuum apparatus. The samples were stored at $-70^{\circ} \mathrm{C}$ until processing and from this point, samples were processed in the same way as serum samples.

The results $(\mathrm{Eq} / \mathrm{gm})$ were calculated by multiplying the result by the luminometer measurement in $\mathrm{Eq} / \mathrm{mL}$ by 100 and dividing by the number of $\mathrm{mg}$ of the liver biopsy specimen. Corrections for possible differences in efficiency of measurement of HCV RNA of different genotypes were done in a similar way as described for serum samples. 


\section{HCV genotyping}

Nineteen patients were genotyped by restriction fragment length polymorphism (RFLP) ${ }^{(15)}$. The amplicons generated from the 5'noncoding region were digested with restriction enzymes HaeIII/RsaI and $B s t N I / H i n f I$ and the products were analyzed to classify HCV into genotypes.

\section{Statistical analysis}

Data were analysed statistically by the Fisher exact test and MannWhitney $\mathrm{U}$ test and the correlation coefficients were determined.

\section{RESULTS}

HCV RNA was detected in 15 of 20 serum specimens and 19 of 20 liver samples by bDNA assay. The weight of the liver samples ranged from 3 to $17 \mathrm{mg}$ (mean $\pm \mathrm{SD}=5.64 \pm 3.67 \mathrm{mg}$ ) when the material was collected by percutaneous liver biopsy and from 25 to $29 \mathrm{mg}$ (mean $\pm \mathrm{SD}=27.8 \pm 1.6 \mathrm{mg}$ ) when the specimens were obtained from liver explants. The only liver sample showing a negative result for bDNA was obtained by percutaneous biopsy; its weight was $8 \mathrm{mg}$. This patient was negative for HCV RNA in serum by bDNA as well, but tested positive for HCV RNA by RT-PCR.

The range and mean values of HCV RNA by bDNA assay in serum and liver are shown in Table 1. RNA values were corrected for differences in efficiency of measurement of HCV RNA in types 1$6^{(19)}$. Nineteen patients were genotyped, 12 were infected with HCV type 1, 6 with type 3 and 1 with type 5 . No difference was observed between the levels of HCV RNA in serum or liver when comparing HCV type 1 and HCV type 3 (Table 2).

TABLE 1 - HCV RNA results by bDNA assay in serum and liver samples

\begin{tabular}{lccc}
\hline bDNA results & n & range & mean \pm SD \\
\hline Serum $(\mathrm{Eq} / \mathrm{mL})$ & 15 & $4 \times 10^{5}-266 \times 10^{5}$ & $94 \times 10^{5} \pm 93 \times 10^{5}$ \\
Liver $(\mathrm{Eq} / \mathrm{gm})$ & 19 & $0.027 \times 10^{8}-7.46 \times 10^{8}$ & $2.1 \times 10^{8} \pm 2.2 \times 10^{8}$ \\
Liver/serum ratio & 15 & $12-267$ & $54.14 \pm 66.23$ \\
\hline
\end{tabular}

$\mathrm{n}=$ number of samples with results above the limit of the test

TABLE 2 - HCV RNA results (mean \pm SD) by bDNA assay in serum and liver samples according to HCV genotypes

\begin{tabular}{lccc}
\hline bDNA results & HCV type 1 & HCV type 3 & P value \\
\hline Serum $(\mathrm{Eq} / \mathrm{mL})$ & $\begin{array}{c}84.2 \times 10^{5} \pm 85.2 \times 10^{5} \\
(\mathrm{n}=11)\end{array}$ & $\begin{array}{c}123.1 \times 10 \pm 121 \times 10^{5} \\
(\mathrm{n}=4)\end{array}$ & NS \\
Liver $(\mathrm{Eq} / \mathrm{gm})$ & $2.5 \times 10^{8} \pm 2.4 \times 10^{8}$ & $1.7 \times 10^{8} \pm 2.2 \times 10^{8}$ & $\mathrm{NS}$ \\
& $(\mathrm{n}=12)$ & $(\mathrm{n}=6)$ & \\
\hline $\begin{array}{l}\mathrm{n}=\text { number of samples with results above the limit of the test; NS=not } \\
\text { significant }\end{array}$ &
\end{tabular}

There was a strong and significant correlation $(\mathrm{r}=0.89 ; P<0.0001)$ between serum and liver HCV-RNA levels (Fig. 1).

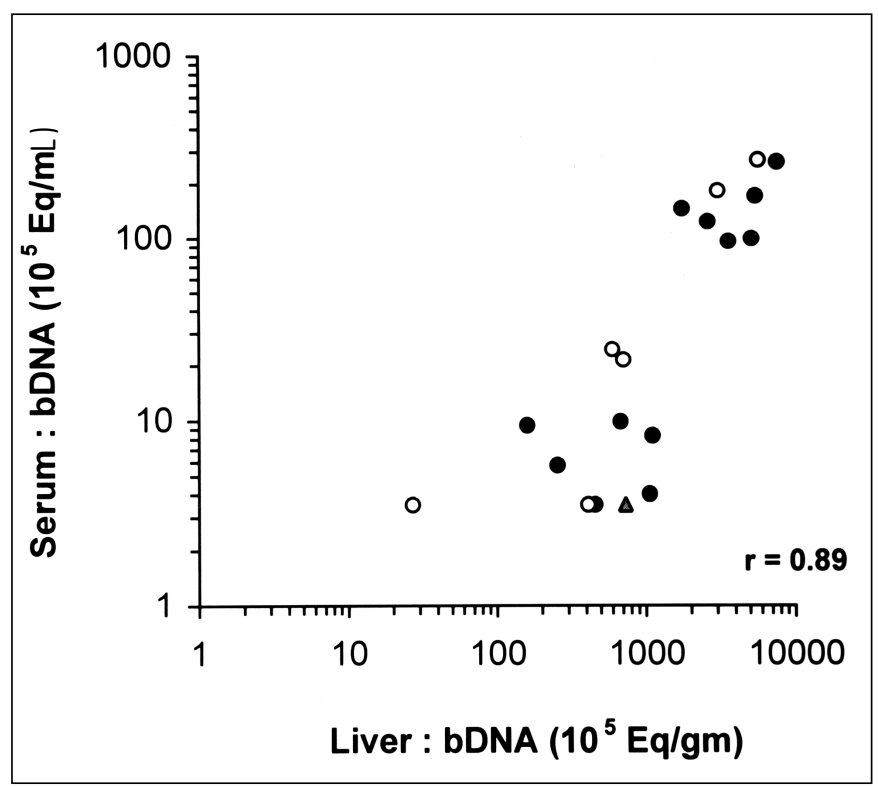

Figure 1 - Strong correlation between HCV RNA results by bDNA assay in serum and liver samples $(P<0.0001)$. The results of four serum samples below the detection limit of the test were depicted as $3.5 \times 10^{5} \mathrm{Eq} / \mathrm{mL}$. HCV genotypes: type 1 , $\bigcirc$ type $3, \boldsymbol{\Delta}$ type 5 .

Histopathological analysis showed chronic hepatitis in 12 patients and cirrhosis in 8 . No difference was observed between cirrhotics and patients with chronic hepatitis regarding HCV RNA levels in the liver however cirrhotic patients showed lower serum HCV RNA concentrations $(P=0.001)$ (Table 3$)$.

TABLE 3 - HCV RNA results (mean \pm SD) by bDNA assay in serum and liver samples in cirrhotics and in patients with chronic hepatitis

\begin{tabular}{lccc}
\hline bDNA results & cirrhotics & chronic hepatitis & $P$ value \\
\hline Serum $(\mathrm{Eq} / \mathrm{mL})$ & $\begin{array}{c}22 \times 10^{5} \pm 34 \times 10^{5} \\
(\mathrm{n}=7)\end{array}$ & $\begin{array}{c}156 \times 10^{5} \pm 81.5 \times 10^{5} \\
(\mathrm{n}=8)\end{array}$ \\
Liver $(\mathrm{Eq} / \mathrm{gm})$ & $1.2 \times 10^{8} \pm 1.6 \times 10^{8}$ & $2.8 \times 10^{8} \pm 2.5 \times 10^{8}$ & $\mathrm{NS}$ \\
& $(\mathrm{n}=8)$ & $(\mathrm{n}=11)$ & \\
Liver/serum ratio & $88.1 \pm 87.3$ & $24.4 \pm 8.1$ & $P=0.01$ \\
\hline $\mathrm{n}=$ number of samples with results above the limit of the test; $\mathrm{NS}=$ not \\
significant
\end{tabular}

Serum ALT and AST ranged from 30 to $266 \mathrm{IU} / \mathrm{L}$ and from 18 to $223 \mathrm{IU} / \mathrm{L}$ respectively; the mean $\pm \mathrm{SD}$ values were $99 \pm 68 \mathrm{IU} / \mathrm{L}$ and $94 \pm 61 \mathrm{IU} / \mathrm{L}$, respectively. There was no correlation between ALT or AST levels in the serum and bDNA results (liver or serum). 


\section{DISCUSSION}

In this study we demonstrated that it is feasible to measure $\mathrm{HCV}$ RNA concentrations in small percutanous liver biopsy samples and there is a strong correlation between serum and liver HCV RNA levels. Our results were true after correction for differences in HCV RNA concentrations obtained using the bDNA (version 1) assay. The results support the hypothesis that serum levels of HCV RNA reflect those in the liver. Similar results were obtained by others ${ }^{(1,10,14,17)}$.

The present results demonstrate that quantitation of HCV RNA in serum provides information about HCV RNA in the liver and suggest that it is not usually necessary to measure hepatic HCV RNA concentrations to stratify treatment approaches. Thus they also support the concept that HCV RNA levels in serum, which reflect viral load in the liver, are valid measurements to predict the response to alphainterferon therapy and for planning drug treatment. Previous studies have not suggested that hepatic HCV RNA distribution between the right and left lobes of the liver will be a confounding variable ${ }^{(6)}$.

Our study, similarly to others ${ }^{(1,10,14,17)}$, has shown a significantly higher concentration of HCV RNA in liver tissue compared to serum. In view of this, measurement of serum viral load is representative of hepatic HCV RNA viral load albeit extrahepatic sites of replication may also contribute.
We did not observe any correlation between ALT and AST levels in the serum and HCV RNA levels in serum or liver.

Lower serum HCV RNA concentrations were observed in patients with cirrhosis in the liver biopsy. However, hepatic HCV RNA concentrations did not differ between cirrhosis and chronic hepatitis. It should be stressed, however, that the number of patients was relatively small, and the significance of this finding should be confirmed. A study of HCV RNA levels in liver samples with different degrees of severity of lesions may help to clarify the mechanisms involved in hepatocellular injury.

In conclusion, serum HCV RNA levels reflect liver HCV RNA levels, so that both can be used successfully in the management of patients with chronic $\mathrm{HCV}$ infection and to monitor their response to antiviral therapy. The strong correlation between serum and hepatic levels supports the employment of serum measurements, as they are more practical.

\section{ACKNOWLEDGEMENTS}

We are grateful to Conselho Nacional de Desenvolvimento Científico e Tecnológico (CNPq) and Fundação de Apoio ao Ensino e Pesquisa e Assistência (FAEPA) of the University Hospital of FMRPUSP for financial support.

Martinelli A de LC, Brown D, Morris A, Dhillon A, Dayley P, Dusheiko G. Quantificação do RNA-HCV no figado de pacientes com hepatite C crônica. Arq Gastroenterol 2000;37(4):203-207.

RESUMO - Introdução/Objetivos - Poucos estudos avaliam a quantificação do RNA-HCV no fígado, portanto a praticabilidade e a aplicação desse parâmetro na avaliação de pacientes com hepatite C crônica ainda não estão definidas. O objetivo foi determinar as concentrações do RNA-HCV no fígado de pacientes com infecção crônica pelo vírus $C$ da hepatite e correlacionar os resultados com a carga viral do soro. Foram também estudadas a relação dos niveis de RNA-HCV no fígado com os de aminotransferases no soro e com a presença de cirrose. Métodos - Foram estudados 20 pacientes (14 homens, 28 a 61 anos). A genotipagem do vírus da hepatite C revelou: tipo 1 (12 pacientes), tipo 3 (6 pacientes), tipo 5 (1 paciente). Amostras de figado foram obtidas por via percutânea em 14 pacientes e de explantes de figado de pacientes submetidos a transplante em 6. Foi observada hepatite crônica em 12 e cirrose em 8. A quantificação do RNA-HCV foi realizada pela técnica do branched-DNA. Resultados - Os níveis de RNA-HCV (média \pm DP) foram de $2.1 \times 10^{8} \pm 2.2 \times 10^{8} \mathrm{Eq} / \mathrm{g}$ de figado e de $94 x$ $10^{5} \pm 93 \times 10^{5} \mathrm{Eq} / \mathrm{mL}$ de soro, com correlação significante entre esses dois parâmetros $(r=0.89 ; P<0.0001)$. Em uma das amostras de figado e em cinco de soro os niveis de RNA-HCV encontravam-se abaixo do limite de detecção. Níveis de RNA-HCV no soro foram menores $(P=0.001)$ em cirróticos do que em pacientes com hepatite crônica; entretanto, os dois grupos não diferiram quanto aos níveis de RNAHCV no fígado. Não houve correlação entre os valores de HCV-RNA no fígado ou soro e os níveis de ALT ou AST. Conclusões - A quantificação do RNA-HCV foi factivel em pequenas amostras de figado. Os valores médios de HCV-RNA no figado foram mais que 1 log. maiores que aqueles do soro; entretanto, houve correlação entre esses parâmetros. Aguardam-se mais estudos para definir o papel da aplicação dessa tecnologia na monitorização da resposta ao tratamento anti-viral e na ampliação dos conhecimentos acerca da patogênese da doença.

DESCRITORES - RNA viral. Hepatite C. Virus semelhantes aos da hepatite C. Fígado. Genotipo. 


\section{REFERENCES}

1. Coelho-Little E, Jeffers LJ, Bartholomew M, Reddy KR, Schiff ER, Dailey PJ. Correlation of HCV-RNA levels in serum and liver of patients with chronic hepatitis C [letter]. J Hepatol 1995;22:508

2. Dusheiko GM. The natural course of chronic hepatitis $\mathrm{C}$ : implications for clinical practice. J Viral Hep 1998;5 Suppl 1:9-12.

3. EASL. International Consensus Conference on Hepatitis C. J Hepatol 1999;30:956-61.

4. Hagiwara H, Hayashi N, Fusamoto H, Kamada T. Quantitative analysis of hepatitis $\mathrm{C}$ virus RNA: relationship between the replicative level and the various stages of the carrier states or the response to interferon therapy. Gastroenterol Jpn 1993;28 Suppl 5:48-51.

5. Hayashi J, Kishihara Y, Yoshimura E, Tani Y, Yamaji K, Ikematsu H, Ishiko H, Kashiwagi S. Relationship of genotype to level of hepatitis $\mathrm{C}$ viraemia determined by competitive polymerase chain reaction. J Infect 1995;30:235-9.

6. Idrovo V, Dailey PJ, Jeffers LJ, Coelho-Little E, Bernstein D, Bartholomew M, Alvarez L, Urdeaa MS, Collins ML, Schiff ER. Hepatitis C virus RNA quantitation in right and left lobes of the liver in patients with chronic hepatitis C. J Viral Hepat 1996;3:239-46.

7. Lau JY, Davis GL, Kniffen J, Qian KP, Urdea MS, Chan CS, Mizokami M, Neuwald PD, Wilber JC. Significance of serum hepatitis C virus RNA levels in chronic hepatitis C. Lancet 1993;341:1501-4.

8. Lau JYN, Simmonds P, Urdea MS. Implications of variations of "conserved" regions of hepatitis C virus genome. Lancet 1995;346:425-6.

9. Magrin S, Craxi A, Fabiano C, Simonetti RG, Fiorentino G, Marino L, Diquattro $\mathrm{O}$, Di Marco V, Loiacono O, Volpes R. Hepatitis C viremia in chronic liver disease: relationship to interferon-alpha or corticosteroid treatment. Hepatology 1994;19:273-9.

10. Martin J, Navas S, Quiroga JA, Colucci G, Pardo M, Carreño V. Quantitation of hepatitis $\mathrm{C}$ virus in liver and peripheral blood mononuclear cells from patients with chronic hepatitis C virus infection. J Med Virol 1998;54:265-70.
11. Morris AJ, Brown D, Martinelli A, Dusheiko GM. Relationship between genotype and viral load in chronic hepatitis $\mathrm{C}$ virus infection. [abstract]. J Hepatol 1994;21 Suppl 1:S36.

12. Nelson DR, Lau JYN. Pathogenesis of hepatocellular damage in chronic hepatitis $\mathrm{C}$ virus infection. In: Glitin N, Davis GL, editors. Clinics in liver disease. Philadelphia: WB Saunders; 1997. p. 515-28.

13. Pawlotsky JM. Hepatitis C virus infection: virus/host interactions. J Viral Hep 1998;5 Suppl 1:3-8.

14. Pessoa MG, Terrault NA, Detmer J, Kolberg J, Collins M, Hassoba HM, Wright TL. Quantitation of hepatitis $\mathrm{G}$ and $\mathrm{C}$ viruses in the liver: evidence that hepatitis $\mathrm{G}$ virus is not hepatotropic. Hepatology 1998;27:877-80.

15. Simmonds P, McOmish F, Yap PL, Chan SW, Lin CK, Dusheiko GM, Saeed AA, Holmes EC. Sequence variability in the 5'non-coding region of hepatitis $\mathrm{C}$ virus: identification of a new virus type and restrictions on sequence diversity. J Gen Virol 1993;74(Pt 4):661-8.

16. Smith DB, Davidson F, Yap PL, Brown H, Kolberg J, Detmer J, Urdea M, Simmonds $\mathrm{P}$, International HCV Collaborative Study Group. Levels of hepatitis C virus in blood donors infected with different viral genotypes. J Infect Dis 1996;173:72730 .

17. Terrault NA, Dailey PJ, Ferrell L, Collins ML, Wilber JC, Urdea MS, Bhandari $\mathrm{BN}$, Wright TL. Hepatitis C virus quantitation and distribution in liver. J Med Virol 1997;51:217-24.

18. Wejstal R. Immune-mediated liver damage in chronic hepatitis C. Scand J Gastroenterol 1995;30:609-13.

19. Yamada G, Takatani M, Kishi F, Takahashi M, Doi T, Tsuji T, Shin S, Tanno M, Urdea MS, Kolberg JA. Efficacy of interferon alpha therapy in chronic hepatitis $\mathrm{C}$ patients depends primarily on HCV RNA level. Hepatology 1995;22:1351-4.

20. Yuki N, Hayashi N, Kasahara A, Hagiwara H, Takehara T, Oshita M, Katayama K, Fusamoto H, Kamada T. Pretreatment viral load and response to prolonged interferon-alpha course for chronic hepatitis C. J Hepatol 1995;22:457-63.

Recebido para publicação em 22/12/1999. Aprovado para publicação em 3/5/2000. 